Available online http://www.lumenpublishing.com/journals/index.php/lumenlaw ISSN: 2284 - 5968 (print), ISSN: 2284 - 5968 (electronic)

Logos Universality Mentality Education Novelty Section: Law

2017, Volume V, Issue 2, December, pp. 93-116

\title{
Sexual Harassment. Micro-research
}

\section{Loredana-Cătălina SPOIALĂ, Raluca-Gabriela ZAHARIE, Maria-Cristina PETREA, Sabina- Mădălina SMOCHINĂ, Maria CLIPA}

https://doi.org/10.18662/lumenlaw.6

Covered in:

CEEOL, Index Copernicus, Ideas RePeC, EconPapers, SocioNet, HeinOnline

(C)2017 The Authors \& LUMEN Publishing House.

Selection, peer review and publishing under the responsibility of LUMEN Publishing House.

How to cite: Spoială, L.-C., Zaharie, R.-G., Petrea, M.-C., Smochină, S.-M., Clipa, M. (2017). Sexual Harassment. Micro-research. Logos Universality Mentality Education Novelty, Section: Law, V(2), 93-116. 


\title{
Sexual Harassment. Micro-research
}

\author{
Loredana-Cătălina SPOIALĂ¹, Raluca-Gabriela ZAHARIE1, Maria-Cristina \\ PETREA $^{1}$, Sabina-Mădălina SMOCHINA ${ }^{1}$, Maria CLIPA ${ }^{1}$
}

\begin{abstract}
The purpose of the paper is to analyze the hypothesis according to which the women in Romania considers sexual harassment to be a serious problem, but it is still expected the solution to occur naturally. In this paper, we want to emphasize that women need to be better informed about sexual harassment and that most of those in such cases are not aware of the law that protects them.
\end{abstract}

Keywords: sexual harassment; exclusion; abuse; discrimination; injured person.

\section{Introducere}

Am ales să realizăm această cercetare pentru că în societatea actuală reprezintă un subiect de importanţă majoră, din ce în ce mai multe persoane de gen feminin fiind victimele acestui fenomen. Totodată, dorim să arătăm faptul că deşi există un număr mare de persoane hărțuite (Agrosoaie et al., 2003), acestea nu au apelat cu încredere la autorități pentru a le sprijini şi pentru a rezolva situațiile cu care s-au confruntat. In cadrul chestionarului vor fi evidențiate şi motivele pentru care cele mai multe dintre persoanele intervievate nu doresc să recunoască faptul că au fost hărțuite de-a lungul vieții, chiar dacă unele dintre ele au ajuns să aibă diferite probleme emoționale sau psihice din cauza acestor întâmplări.

\section{Eşantionarea}

Chestionarul a fost aplicat unui eşantion (Sandu, 2016) alcătuit din 200 de persoane de gen feminin care locuiesc pe raza județului Suceava. Acestea au fost alese aleatoriu, tocmai pentru a reuşi să vedem dacă acest fenomen este într-adevăr răspândit şi în județul nostru şi pentru a înțelege cum gândesc persoanele aflate în cauză referitor la acest subiect, considerat de multe ori şi tabu. Vârsta persoanelor intervievate a fost între 18-60 de ani.

Tema acestei cercetări este reprezentată de situația femeilor care s-au confruntat cu hărțuirea sexuală şi care nu au ştiut cum să procedeze pentru a se apăra. Cercetarea este de tip explicativ, deoarece intenția noastră este de a

\footnotetext{
${ }^{1}$ Student, Faculty of Law and Administrative Sciences, Stefan cel Mare University from Suceava, Romania.
} 
analiza modalitățile prin care se poate manifesta hărțuirea sexuală şi modurile de a le preveni. Dorim de asemenea să arătăm faptul că femeile nu recunosc că au întâmpinat astfel de incidente şi că li se pare ruşinos să o facă.

Chestionarul este alcătuit din 32 de întrebări, atât cu un singur răspuns, cât şi cu răspuns multiplu. În cele ce urmează vom prezenta rezultatele pe care am reuşit să le obținem.

\section{Interpretarea rezultatelor cercetării}

La întrebarea "Ce înțelegeți prin sintagma hărțuire sexuală", 61\% din persoanele chestionate (122 de persoane) consideră hărțuirea sexuală „un comportament prin care victima este determinată să ofere favoruri sexuale prin intimidare, ameninţare sau constrângere”, iar 39\% (78 de persoane) consideră că hărțuirea sexuală reprezintă "orice comportament care este nedorit şi face o femeie să se simtă incomod". Nici o persoană din cele chestionate nu consideră hărțuirea ca fiind un flirt intenționat sau un mijloc de a atrage atenția unei femei. R.S

Ce înțelegeți prin sintagma "hărțuire sexuală" ?

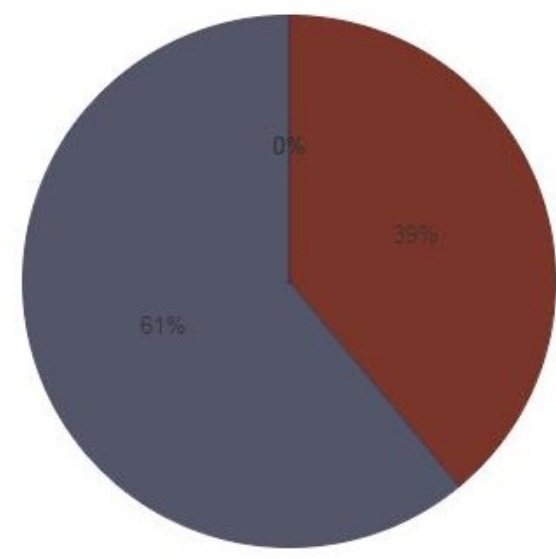

Flirtul intentionat.

Orice mijloc folosit pentru atragerea atentiei unei femei.

Orice comportament care este nedorit și face o femeie să se simtă incomod.

Comportamentul prin care victima este determinată să ofere favoruri sexuale prin intimidare, ameninţare sau constrângere

La întrebarea: “Ce tipuri de hărţuire sexuală cunoaşteţi?” (întrebare cu răspuns multiplu) persoanele chestionate au dovedit că într-adevăr cunosc diferite tipuri ale acestui fenomen, dar nu pe toate într-o măsură egală: $25.9 \%$ din persoanele chestionate (171 de persoane) sunt familiare cu tipul hărțuirii fizice (atingeri şi mângâieri); 24.6\% (162 de persoane) cunosc tipul

How to cite: Spoiala, L.-C., Zaharie, R.-G., Petrea, M.-C., Smochina, S.-M., Clipa, M. (2017). Sexual Harassment. Micro-research. Logos Universality Mentality Education Novelty, Section: Law, V(2), 93-116. https://doi.org/10.18662/lumenlaw.6 
hărțuirii verbale; 15.9\% (105 persoane ) au auzit despre Hărțuirea Quid pro quo (amenințări cu pierderea locului de muncă sau refuzarea unor beneficii la locul de muncă); 8\% (53 de persoane) cunosc hărţuirea în mediul educațional, iar 25.5\% (168 de persoane) cunosc hărțuirea fizică dusă la extreme (viol şi agresiuni). R.M

Ce tipuri de hărțuire sexuală cunoașteți ?
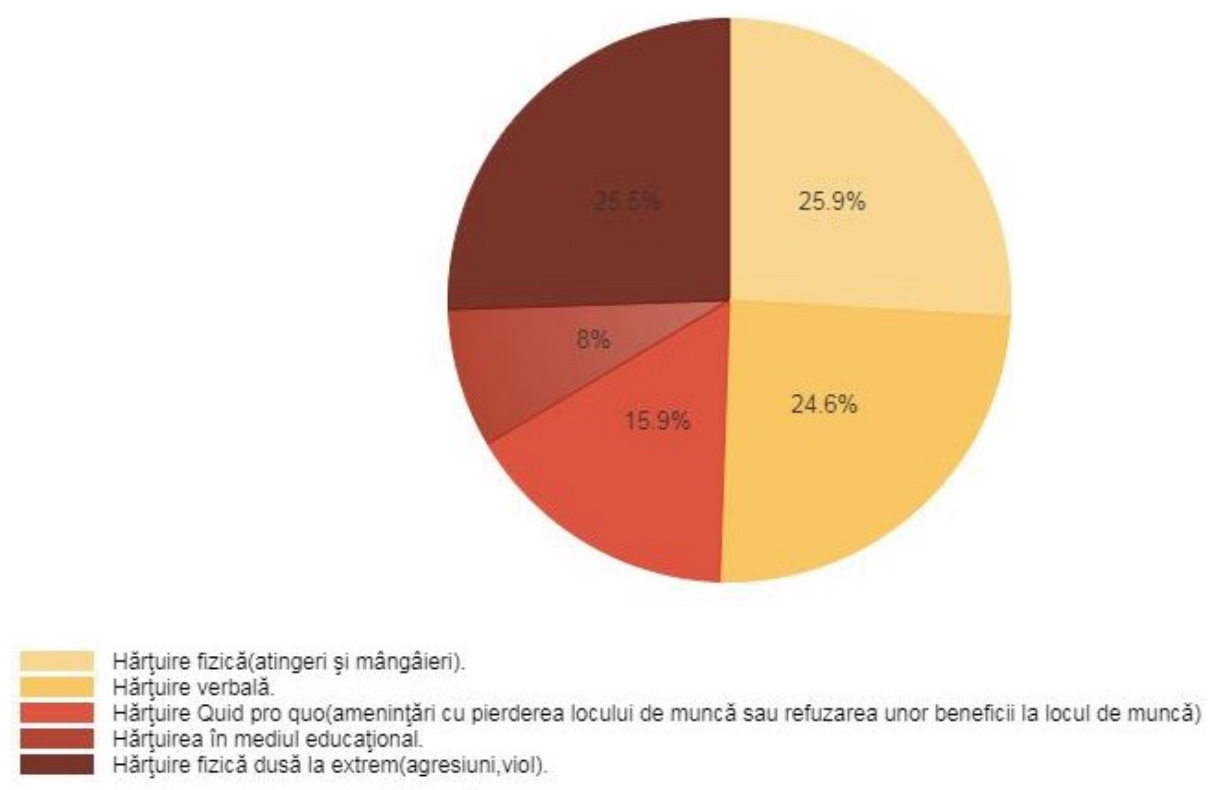

A treia întrebare propusă celor chestionaţi a fost recunoaşterea acestei imagini:

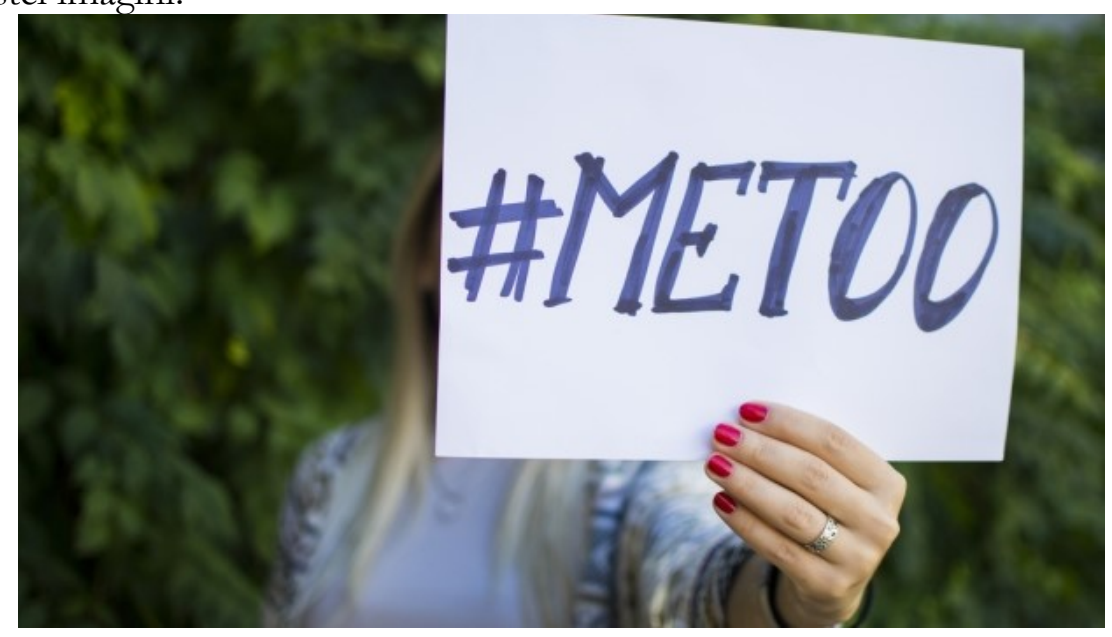

95

How to cite: Spoiala, L.-C., Zaharie, R.-G., Petrea, M.-C., Smochina, S.-M., Clipa, M. (2017). Sexual Harassment. Micro-research. Logos Universality Mentality Education Novelty, Section: Law, V(2), 93-116. https://doi.org/10.18662/lumenlaw.6 
În proporție de $44.5 \%$ (89 de persoane) au recunoscut faptul că întradevăr cunosc semnificația acestei imagini, respectiv a campaniei împotriva hărțuirii care stă la baza ei; 33.5\% (67 de persoane) au spus că nu cunosc semnificația acesteia; $13.5 \%$ (27 de persoane) au răspuns că este posibil să o cunoască, fiindcă li se pare cunoscută, iar $8.5 \%$ (17 persoane) au spus că au mai întâlnit-o, dar nu cunosc povestea din spatele ei. R.S

Cunoaşteți semnificația acestei imagini?

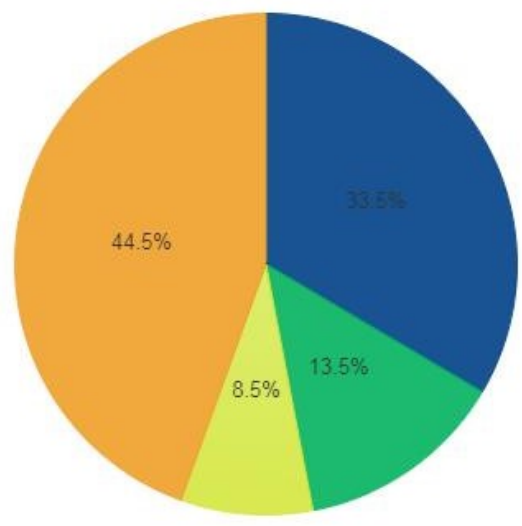

\footnotetext{
Nu. Nu știu despre ce este vorba. Posibil, mi se pare cunoscuta

Nu cunosc semnificatia, dar am mai întâlnit-o.
}

$\mathrm{Da}$, cunosc seminificația. Este vorba despre campania împotriva hărţuirii sexuale.

In proporție de 40.5\% (81 de persoane), repondenții au susținut faptul că nu sunt sigure dacă în oraşul în care locuiesc există incidente de hărțuire sexuală; 28\% (56 de persoane) au spus că există din ce în ce mai multe; $25.5 \%$ (51 de persoane) au susținut faptul că există, dar puține; 5\% (10 persoane) spun că incidentele sunt foarte rare, iar cel mai mic procentaj de 1\% (2 persoane) susține că oraşul este unul sigur. R.S

How to cite: Spoiala, L.-C., Zaharie, R.-G., Petrea, M.-C., Smochina, S.-M., Clipa, M. (2017). Sexual Harassment. Micro-research. Logos Universality Mentality Education Novelty, Section: Law, V(2), 93-116. https://doi.org/10.18662/lumenlaw.6 


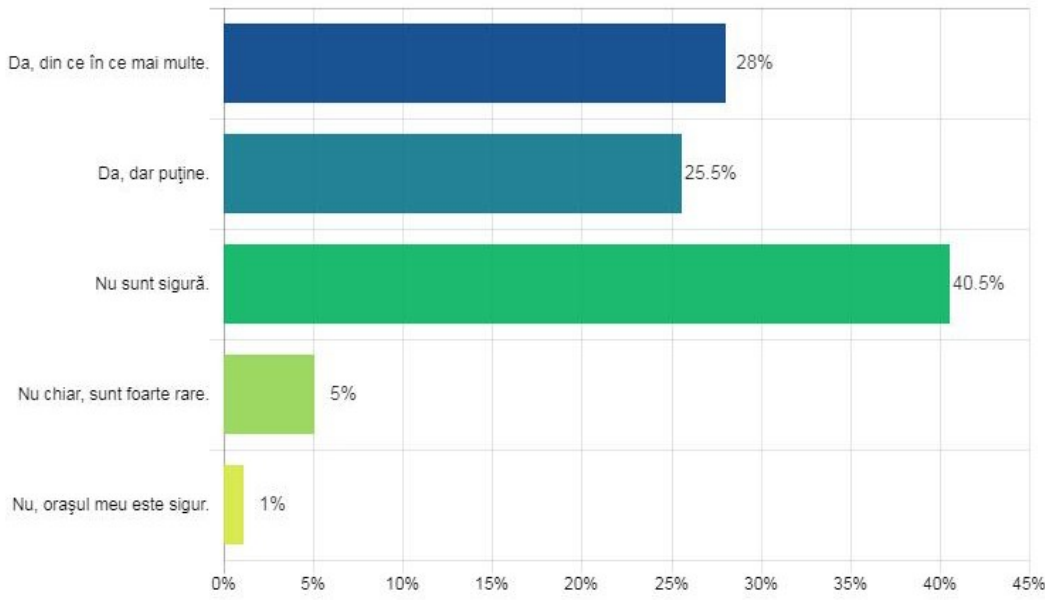

Persoanele chestionate consideră că aceste cazuri sunt mai frecvente în oraşul lor, în diferite locuri: 55.4\% (159 de persoane) consideră cele mai multe incidente întâmplate pe străzi, în parcuri sau alte locuri publice; $15.3 \%$ (44 de persoane) consideră că incidentele sunt frecvente în trasportul public, iar de asemenea 15.3\% (44 de persoane) consideră că incidentele sunt frecvente la locul de muncă. 7\% (20 de persoane) din respondenți consideră că sunt mai frecvente în mediul educațional, iar în aceeaşi proporție 7\% (20 de persoane) consideră că aceste incidente nu există în oraşul în care locuiesc. R.M

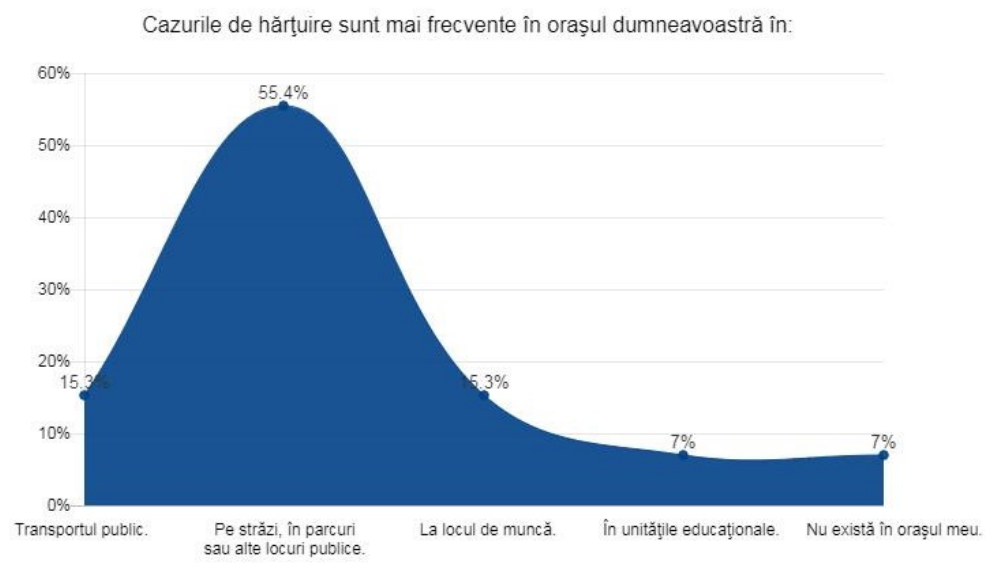

La întrebarea „Cunoaşteți legislaţia în vigoare în România în acest moment cu privire la acest fenomen?” 39.5\% (79 de persoane) au răspuns “o mică parte"; 39\% (78 de persoane) au spus că nu o cunosc; 14.5\% (29 de 
persoane) o cunosc, iar 7\% (14 persoane) au recunoscut că nu au fost interesate niciodată. R.S

Cunoașteți legislația în vigoare în România în acest moment cu privire la acest fenomen ?
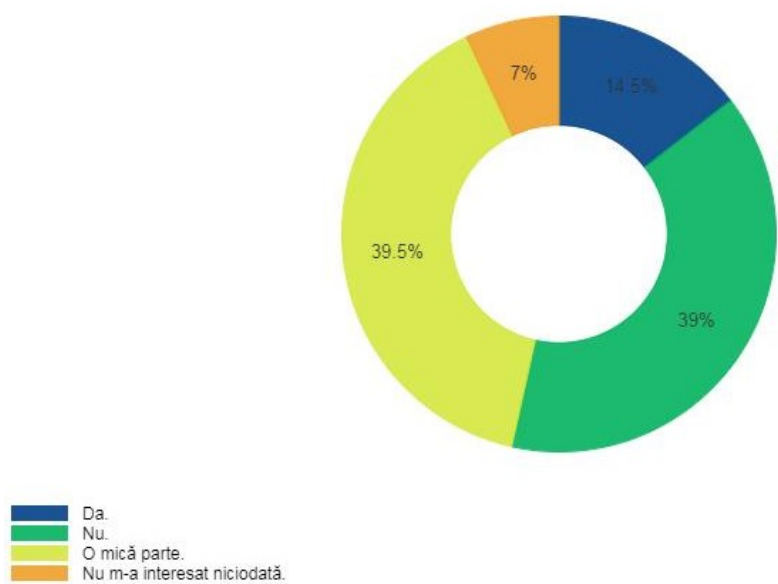

Un număr destul de mare dintre cei chestionați, respectiv 57.5\% (115 persoane) spun că sunt îngrijorați în legătură cu acest subiect, 39\% (78 persoane) recunosc că sunt total îngrijorați, 3.5\% (7 persoane) spunând că nu sunt siguri şi nici un respondent nu a susținut că această problemă ar fi neserioasă sau trecătoare R.S

Considerați că problema hărțuirii sexuale este una de importanță majoră?

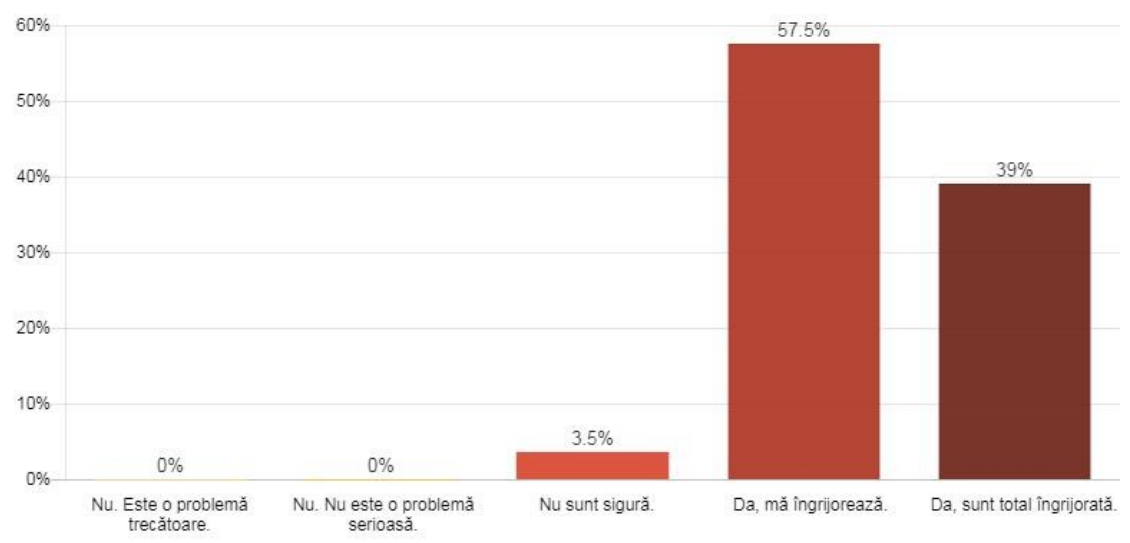

How to cite: Spoiala, L.-C., Zaharie, R.-G., Petrea, M.-C., Smochina, S.-M., Clipa, M. (2017). Sexual Harassment. Micro-research. Logos Universality Mentality Education Novelty, Section: Law, V(2), 93-116. https://doi.org/10.18662/lumenlaw.6 
Întrebarea "În medie, ați auzit/observat tentative de hărțuire în diferite forme" a primit următoarele răspunsuri: 41\% (82 de persoane) de 2-3 ori, 29.5\% (59 de persoane) mai mult de 5 ori, $17.5 \%$ (35 de persoane) niciodată, iar $12 \%(24$ de persoane) o singură dată. R.S

În medie, ați auzit/observat tentative de hărţuire în diferite forme:

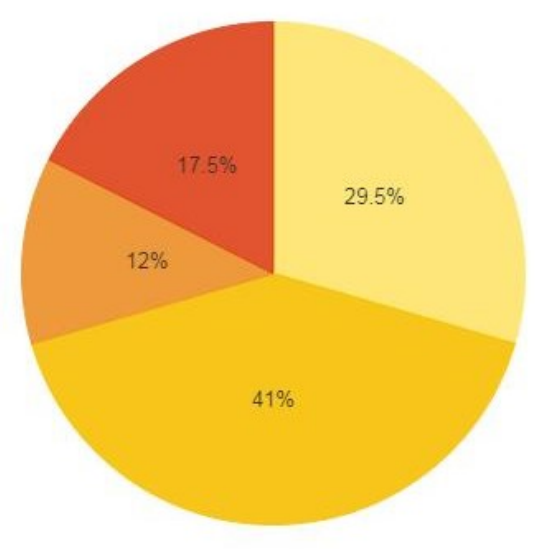

Întrebarea numărul 9 a avut 2 răspunsuri, respectiv Da şi Nu. Astfel, 79\% (140 de persoane) din persoanele chestionate susțin că nu au fost hărțuite sexual vreodată, iar 30\% (60 de persoane) recunosc că da, au fost hărțuite. R.S

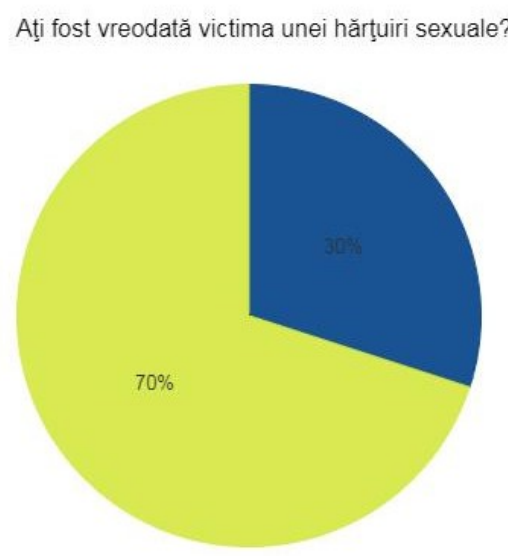


Fiind întrebate despre forma hărțuirii sexuale, de această dată doar 51.6\% (128 de persoane) din persoanele care au susținut la întrebarea anterioară că nu au fost victime, au susţinut şi aici acelaşi lucru. Acest lucru denotă o mică eroare de interpretare, datorită faptului că atunci când au întâlnit şi cazurile de hărţuire, persoanele chestionate au considerat că au fost cel puțin o dată hărțuite, chiar şi în cel mai inofensiv mod. 18.5\% (46 de persoane) au spus că au fost hărțuite fizic, prin atingeri şi mângâieri, 20.2\% (50 de persoane) au fost hărțuite verbal, 4\% (10 persoane) s-au confruntat cu o hărțuire fizică dusă la extreme (agresiuni şi viol), 3.2\% (8 persoane) au fost hărţuite în mediul educaţional, $2.4 \%$ (6 persoane) s-au confruntat cu amenințări cu pierderea locului de muncă sau alte tipuri ale hărțuirii Quid pro quo. R.M

Daca da, în ce formă a acesteia?

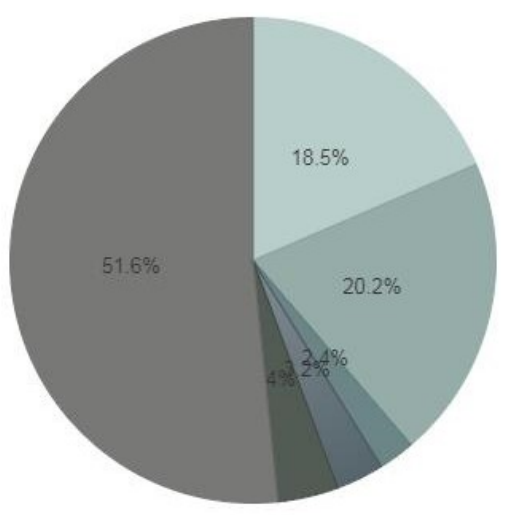

Hărtuire fizică(atingeri și mângâieri)

Hărtuire verbală.

Hărțire Quod pro quo(amenintări cu pierderea locului de muncă sau refuzarea unor beneficii la acesta)

Hărţuire în mediul educațional.

Hărţuire fizică dusă la extrem(viol, agresiuni)

Nu, nu am fost victimă

$5.5 \%$ (11 persoane) din persoanele chestionate susțin că incidentul respectiv s-a produs recent, $10.5 \%$ (21 de persoane) susțin că acesta a avut loc cu mai puțin de 2 ani în urmă, 21\% (42 de persoane) spun că a avut loc cu mai mult de 2 ani în urmă, iar 63\% (126 de persoane) susțin că nu au întâmpinat vreodată un astfel de eveniment. R.S 


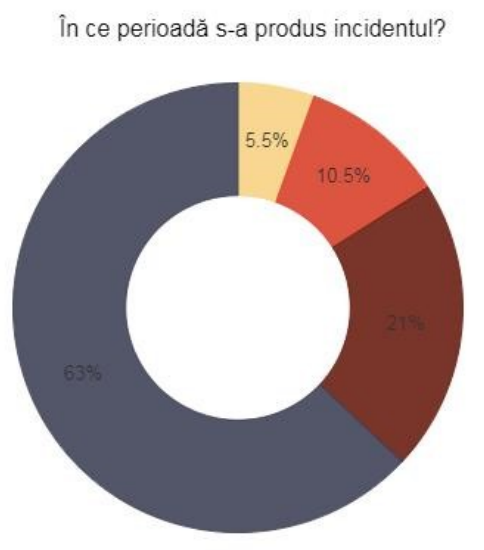

La întrebarea „Cine a fost persoana care v-a hărţuit?”, respondenții au spus: 18.2\% (40 de persoane) o persoană cunoscută, 17.7\% (39 de persoane) o persoană necunoscută, 4.1\% (9 persoane) un prieten, $0.9 \%$ (2 persoane) şeful, 1.4\% (3 persoane) un profesor şi $57.7 \%$ susțin din nou că nu au fost hărțuite.(127 de persoane). R.M

Cine a fost persoana care v-a hărțuit?
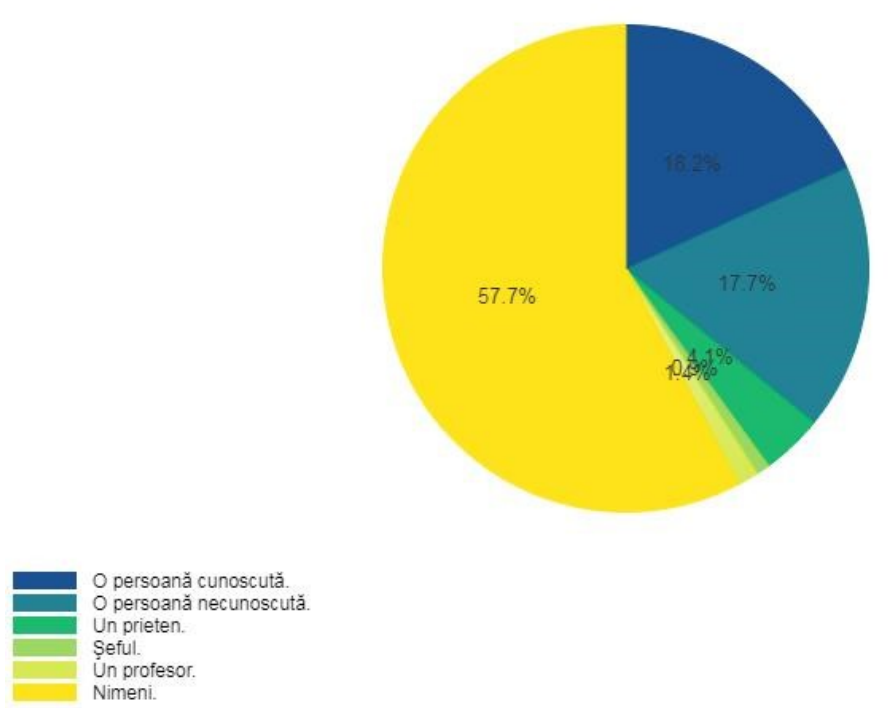
Natura hărțuirii pe care au experimentat-o persoanele chestionate a fost de diferite tipuri: 3\% (11 persoane) au avut relații sexuale nedorite, $12.4 \%$ (46 de persoane) au avut contact fizic deranjant (atingeri, ciupit), 7.6\% (28 de persoane) au primit comentarii neplăcute la adresa corpului lor, 11.6\% (43 de persoane) au primit comentarii verbale agasante, 4.3\% (16 persoane) au primit telefoane agasante, $8.4 \%$ (31 de persoane) au primit propuneri de natură sexuală, 3.8\% (14 persoane) au fost puşi în situația de a le fi expuse obiecte indecente cu tentă sexuală, 5.1\% (19 persoane) au întâmpinat contact vizual cu tentă sexuală (persoane care se masturbează în jurul lor), 10.8\% (40 de persoane) au întâlnit limbaj cu conotație sexuală și în final 33\% (122 de persoane) susțin din nou că nu au fost hărțuite. Însă şi de această dată numărul persoanelor nu conincide cu cel anterior, reieşind faptul că unele persoane nu realizează că, de fapt, există şi forme minore ale hărțuirii sexuale, inițial susținând că nu au fost hărțuite, iar mai apoi la această întrebare bifând totuşi anume moduri prin care consideră că au fost hărțuite.

\section{R.M}

Care a fost natura hărțuirii?

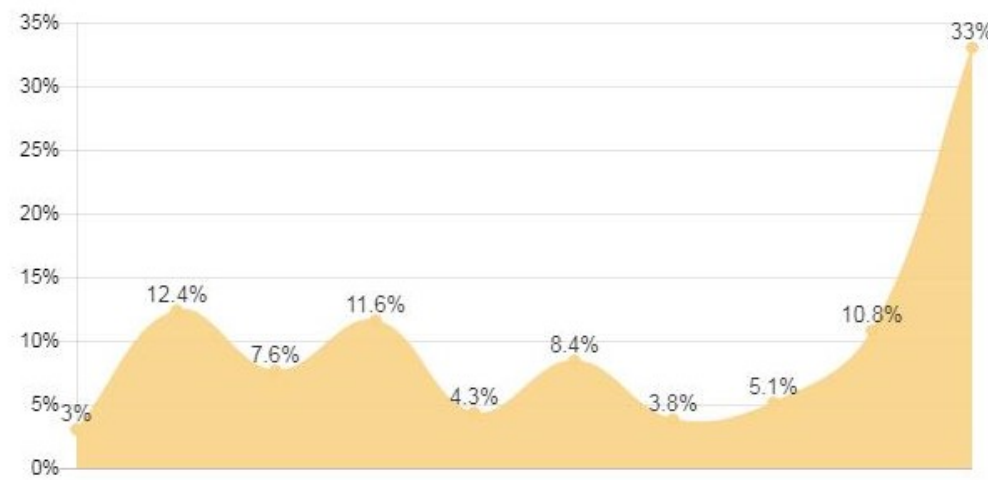

Relatii sexuale nedorite.

Contact fizic deranjant(atingeri, ciupit)

Comentarii neplăcute la adresa corpului dumneavoastră

Comentarii verbale agasante(fluierături, strigăte)

Telefoane agasante.

Propuneri de natură sexuală

Expunerea unor obiecte indecente cu tentă sexuală

Contact vizual cu tentă sexuală(persoane care se masturbează în jurul dumneavoastră)

Limbaj cu conotatie sexuală.

Nu am fost hărţuită.

În proporție de 87.5\% (175 de persoane) aceste persoane susțin că nu au fost ameninţate odată cu refuzul la unele propuneri indecente (printre acestea numărându-se şi cele care nu au fost victime), iar 12.5\% (25 de persoane) susțin că au fost ameninţate. R.S 


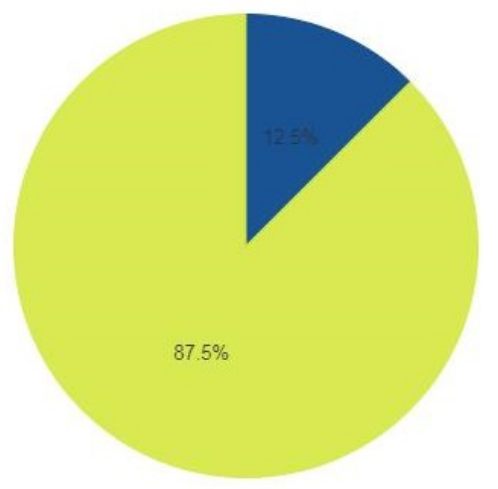

\section{Da.}

Fiind întrebate ce măsuri au luat odată cu începerea acestui fenomen în viața lor, am primit următoarele răspunsuri: 14\% (30 de persoane) susțin că nu au făcut nimic, $0.5 \%$ (1 persoană) au spus că nu au făcut nimic şi că nu văd nici un rost în a lua inițiativă, 17.3\% (37 de persoane) au spus că au rezolvat pe cale neoficială, prin discuții cu hărțuitorul, $0.9 \%$ (2 persoane) au reclamat incidentul autorităţilor, $12.1 \%$ (26 de persoane) au sperat că va trece, nici o persoană nu a iniţiat vreo acțiune în instanţă, iar 55.1\% (118 persoane) au susținut din nou că nu au fost victime ale unui astfel de incident. R.M

Ce ați făcut în legătură cu hărţuirea?

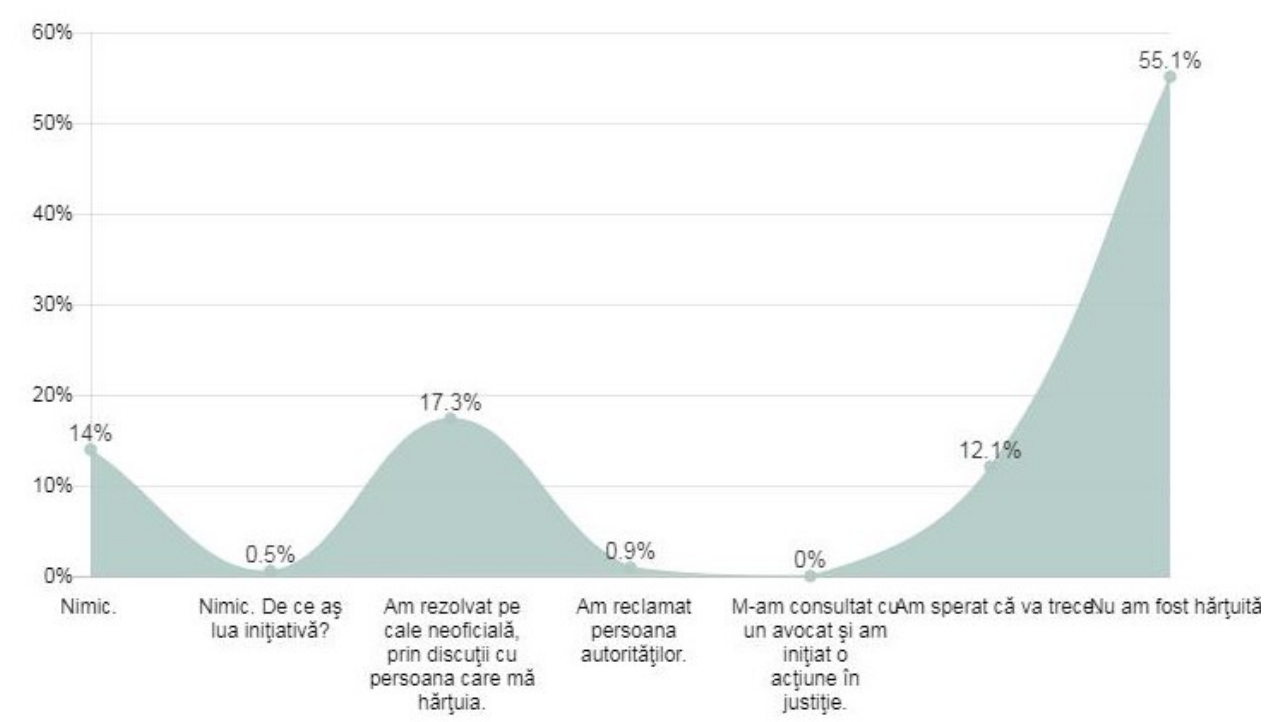


Cu privire la măsurile luate împotriva lor odată cu refuzarea hărțuirii, respondentele au spus că: faţă de $2.5 \%$ ( 5 persoane) au fost luate măsuri, $0.5 \%$ (1 persoană) nu a promovat examenele din cauza aceasta, 22\% (44 de persoane) au spus că nu au fost luate măsuri împotriva lor, 16.5\% (33 de persoane) au susținut că totul a încetat în acel moment, 58.5\% (117 persoane) au susținut din nou că nu au fost hărțuite, promovarea la locul de muncă sau pierderea acestuia nefiind situații întâmpinate de nimeni. R.S

Au fost luate măsuri împotriva dumneavostră fiindcă ați refuzat hărțuirea?

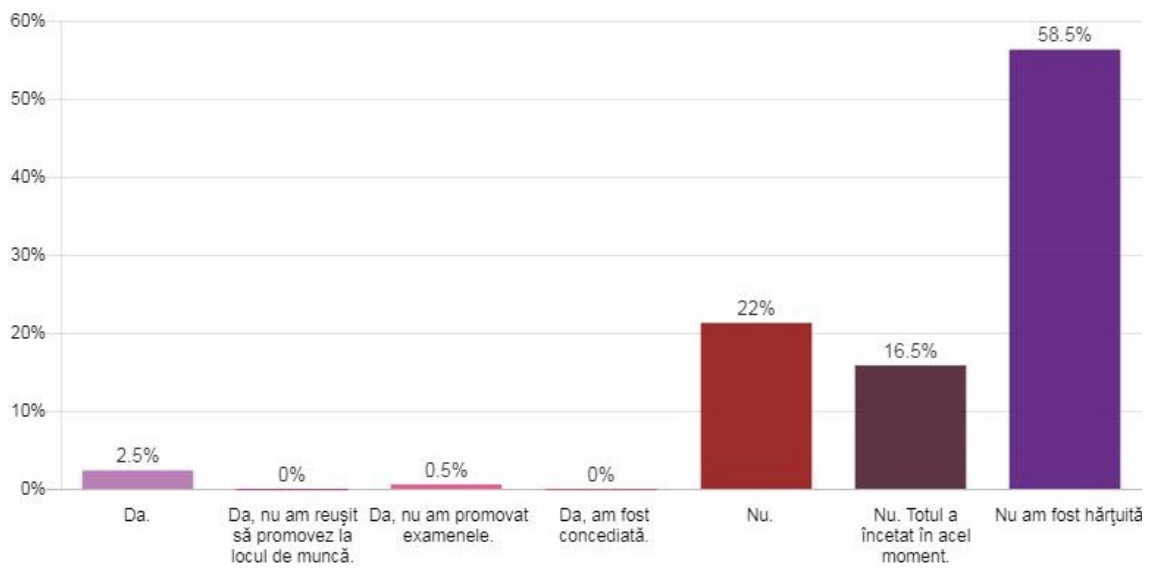

La întrebarea "În cazul în care ați apelat la autorități, acestea v-au fost de ajutor?,, 1.5\% (3 persoane) spun că autorităţile le-au fost de ajutor, 2.5\% (5 persoane) susțin că autoritățile nu le-au fost de folos, 59.5\% (119 persoane) au spus că nu au apelat la autorităţi, iar 36.5\% (73 de persoane) au spus că nu au fost hărțuite. R.S 


\section{În cazul în care ați apelat la autorități, acestea v-au fost de ajutor?}

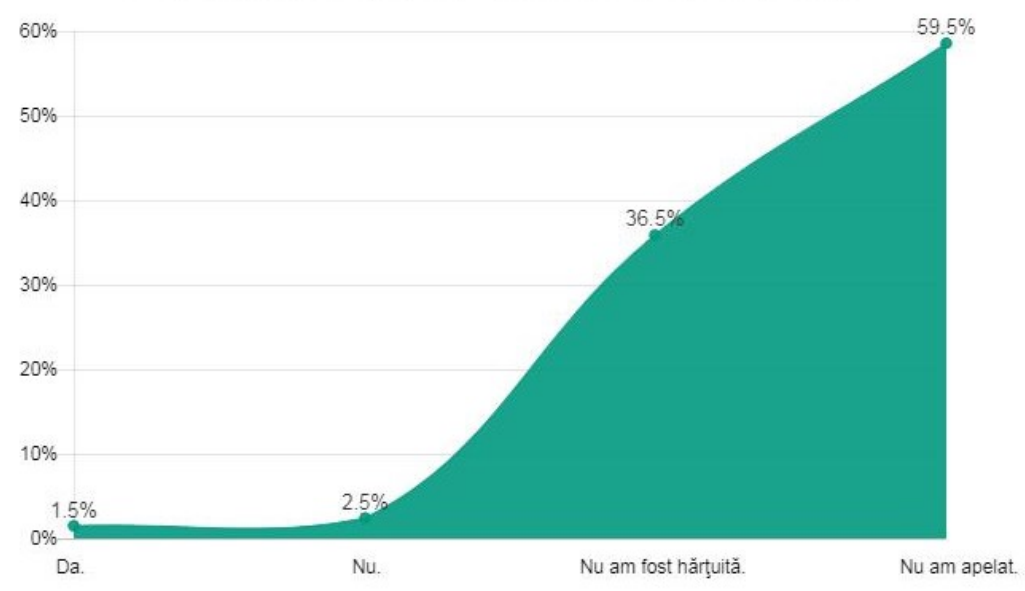

Fiind întrebate cum s-au simțit atunci când au fost victime, acestea au spus: $16.8 \%$ (56 de persoane) s-au simțit speriate, $11.7 \%$ (39 de persoane) s-au simțit iritate, $13.2 \%$ (44 de persoane) s-au simțit neajutorate, $13.8 \%$ (46 de persoane) s-au simțit ruşinate, $8.4 \%$ (28 de persoane) s-au simțit nesigure, $0.3 \%$ (1 persoană) a susținut că nu a simțit nimic, nicio persoană nu a susținut faptul că i-a plăcut, iar 35.7\% (119 persoane) au spus că nu au fost victime. R.M

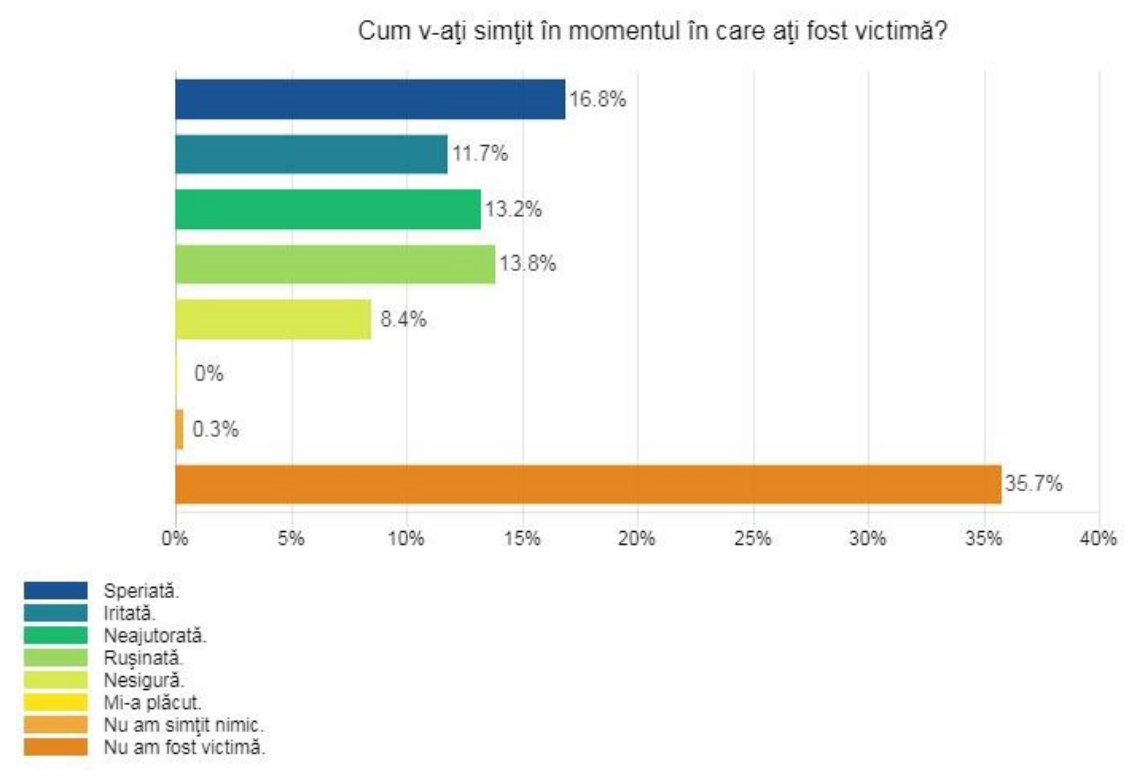


Cele mai multe persoane dintre cele ce au întâmpinat un astfel de incident au rămas cu traume la nivel emoțional, respectiv 17.4\% (42 de persoane), $12.9 \%$ (31 de persoane) au spus doar că au fost marcate, 11.6\% (28 de persoane) au susținut că au traume la nivelul psihicului, 8.3\% (20 de persoane) susțin că nu au rămas marcate, $1.2 \%$ (3 persoane) invocă alte tipuri de traume (Frica de a ieşi pe stradă noaptea neînsoțită, am probleme în ceea ce priveşte relaționarea cu bărbații, mă sperie, sunt speriată pe stradă, am impresia că sunt urmărită, etc.), iar 48.5\% susțin că nu au fost victime. R.M

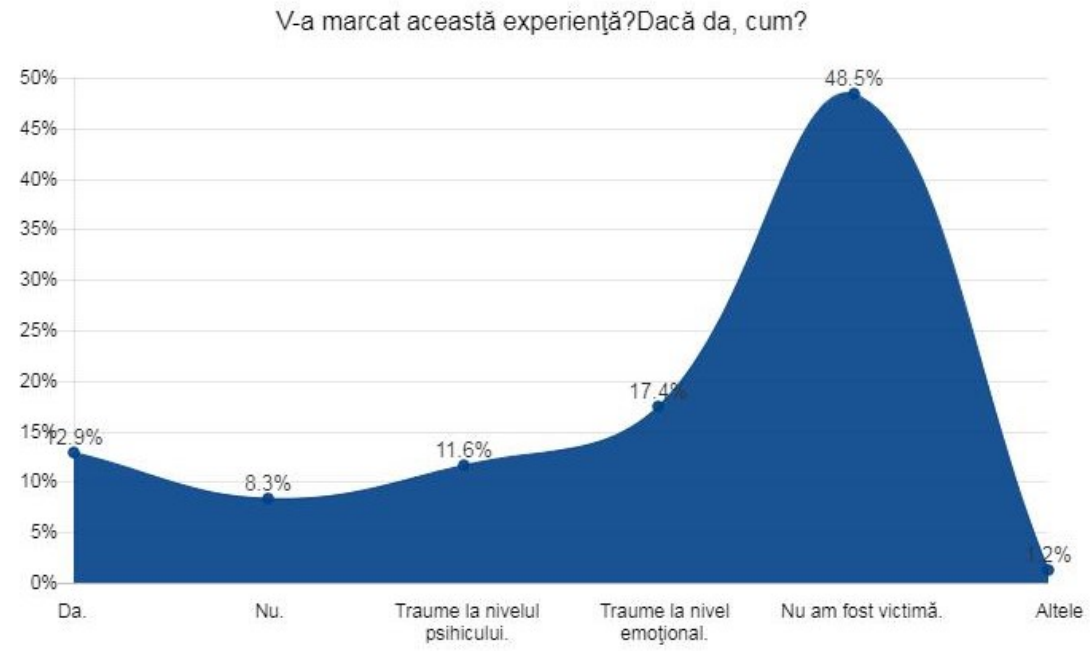

Circa 22.7\% din respondenți (47 de persoane) susțin că nu şi-au schimbat părerea în legătură cu persoanele de gen masculin datorită evenimentelor pe care le-au experimentat, findcă nu sunt toate persoanele la fel, 11.6\% (24 de persoane) susțin că da, şi-au schimbat părerea referitor la persoanele de acest gen, $7.7 \%$ (16 persoane) au spus că şi-au schimbat părerea şi nu mai au încredere în astfel de persoane, 3.4\% (7 persoane) spun că nu şi-au schimbat părerea, iar 54.6\% (113 persoane) susțin că nu au fost victime. R.M 


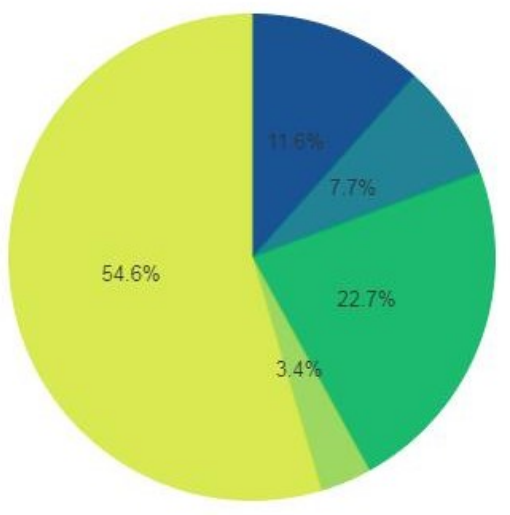

Fiind întrebate cum cred că ar reacționa persoanele din jur dacă ar afla de incidentele lor, respondentele susțin: 13.4\% (28 de persoane) cred că vor fi înțelese, $23.4 \%$ (49 de persoane) nu ştiu ce să răspundă, 7.2\% (15 persoane) consideră că persoanele din jur for fi indiferente, iar 56\% (117 persoane) susțin că nu au fost victime. R.M

Cum credeți că ar reacționa cei din jur dacă ar afla de incidentul dumneavoastră?

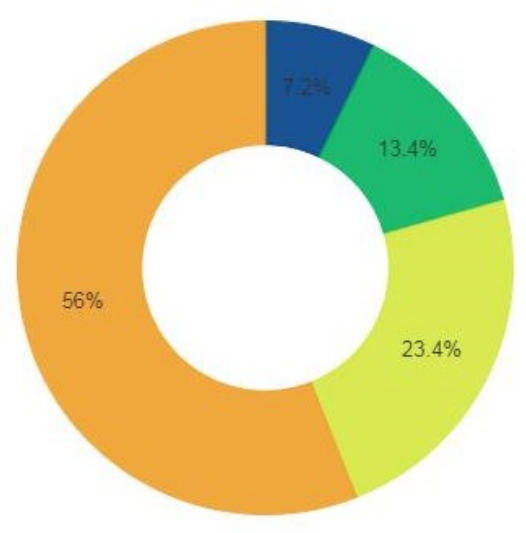


In funcție de cazurile cunoscute, persoanele chestionate au fost rugate să evalueze anumite tipuri de hărțuire: R.S

\begin{tabular}{lcc} 
Urmărire & 54 & $27 \%$ \\
Niciodată & 81 & $40.5 \%$ \\
\hline Rar & 56 & $28 \%$ \\
\hline Des & 9 & $4.5 \%$ \\
\hline Foarte des & & \\
\hline
\end{tabular}

\begin{tabular}{|c|c|c|}
\hline Fluierat & & \\
\hline Niciodată & 11 & $5.5 \%$ \\
\hline Rar & 45 & $22.5 \%$ \\
\hline Des & 75 & $37.5 \%$ \\
\hline Foarte des & 69 & $34.5 \%$ \\
\hline
\end{tabular}

\begin{tabular}{lcc} 
Atingeri inconfortabile & 56 & $28 \%$ \\
Niciodată & 93 & $46.5 \%$ \\
\hline Rar & 44 & $22 \%$ \\
\hline Des & 7 & $3.5 \%$ \\
\hline Foarte des & &
\end{tabular}

\begin{tabular}{|c|c|c|}
\hline Niciodată & 18 & $9 \%$ \\
\hline Rar & 79 & $39.5 \%$ \\
\hline Des & 63 & $31.5 \%$ \\
\hline Foarte des & 40 & $20 \%$ \\
\hline
\end{tabular}

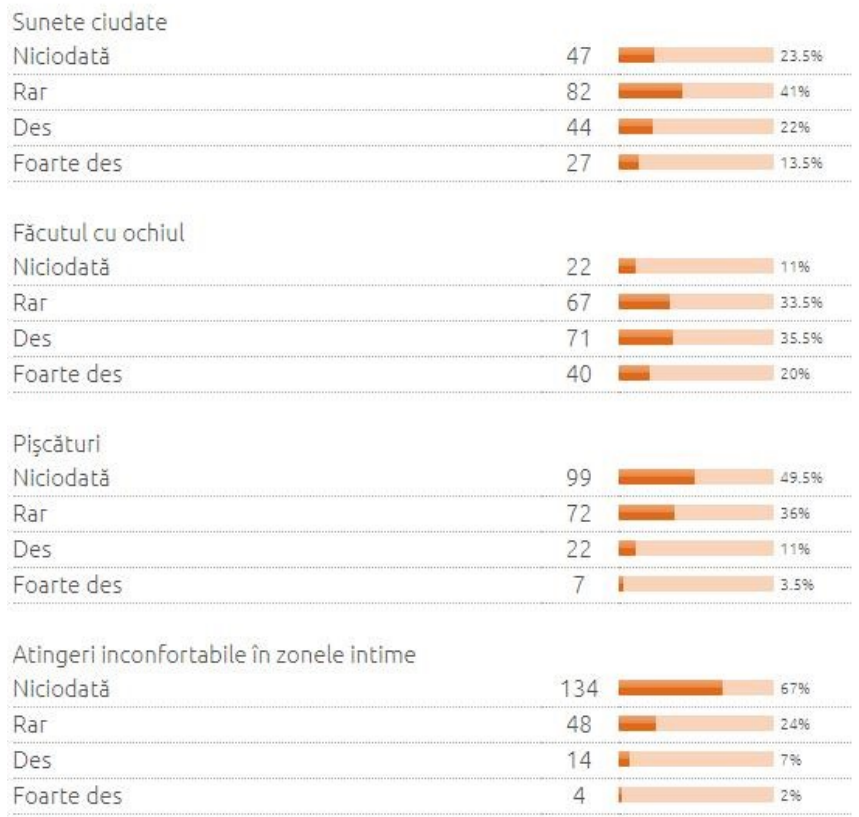




\begin{tabular}{l|c|c} 
Masturbare în public & & \\
Niciodată & 140 & $70 \%$ \\
\hline Rar & 44 & $22 \%$ \\
\hline Des & 13 & $6.5 \%$ \\
Foarte des & 3 & $1.5 \%$
\end{tabular}

În funcție de cazurile experimentate, persoanele chestionate au fost rugate să evalueze anumite tipuri de hărțuire: R.S

\begin{tabular}{|c|c|c|}
\hline Niciodată & 105 & $52.5 \%$ \\
\hline Rar & 71 & $35.5 \%$ \\
\hline Des & 22 & $11 \%$ \\
\hline Foarte des & 2 & $1 \%$ \\
\hline \multicolumn{3}{|l|}{ Fluierat } \\
\hline Niciodată & 23 & $11.5 \%$ \\
\hline Rar & 70 & $35 \%$ \\
\hline Des & 75 & $37.5 \%$ \\
\hline Foarte des & 32 & $16 \%$ \\
\hline \multicolumn{3}{|c|}{ Atingeri inconfortabile } \\
\hline Niciodată & 110 & 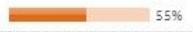 \\
\hline Rar & 59 & 29.596 \\
\hline Des & 30 & $15 \%$ \\
\hline Foarte des & 1 & $0.5 \%$ \\
\hline \multicolumn{3}{|c|}{ Comentarii deocheate despre corpul dumneavoastră } \\
\hline Niciodată & 44 & $22 \%$ \\
\hline Rar & 86 & $43 \%$ \\
\hline Des & 48 & $24 \%$ \\
\hline Foarte des & 22 & $11 \%$ \\
\hline
\end{tabular}

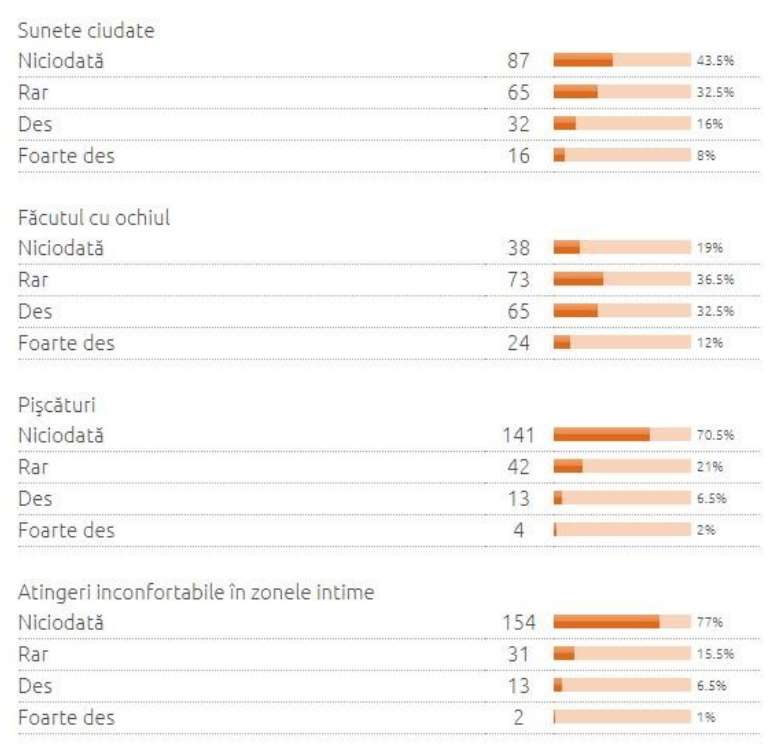

How to cite: Spoiala, L.-C., Zaharie, R.-G., Petrea, M.-C., Smochina, S.-M., Clipa, M. (2017). Sexual Harassment. Micro-research. Logos Universality Mentality Education Novelty, Section: Law, V(2), 93-116. https://doi.org/10.18662/lumenlaw.6 


\begin{tabular}{lcc} 
Masturbare în public & $155 \sqrt{27.5 \%}$ \\
$\begin{array}{l}\text { Niciodată } \\
\text { Rar }\end{array}$ & 29 & $14.5 \%$ \\
\hline Des & 13 & $6.5 \%$ \\
\hline Foarte des & 3 & $1.5 \%$ \\
\hline
\end{tabular}

În opinia respondenților, unii bărbați recurg la hărţuire pentru că: 10.3\% (56 de persoane) consideră că aceştia recurg la astfel de gesturi crezând că sunt amuzante, 1.8\% (10 persoane) cred că îi ajută să treacă timpul mai repede, $21.9 \%$ (119 persoane) au spus că ei cred că este mai bărbătesc acest comportament, $24.1 \%$ (131 de persoane) au susținut faptul că aceşti bărbați sunt frustrați, $11.8 \%$ (64 de persoane) au spus că ei recurg la un astfel de comportament fiindcă ştiu că nu vor fi pedepsiți, 13.6\%(74 de persoane) au spus că aceştia cred că femeilor le place, 2.2\% (12 persoane) susțin că femeile cer acest lucru, $14.3 \%$ (78 de persoane) au spus că aceşti bărbaţi consideră că femeile nu le vor acorda atenție decât dacă vor face asta. R.M

În opinia dumneavoastră, unii bărbați recurg la hărțuire pentru că:
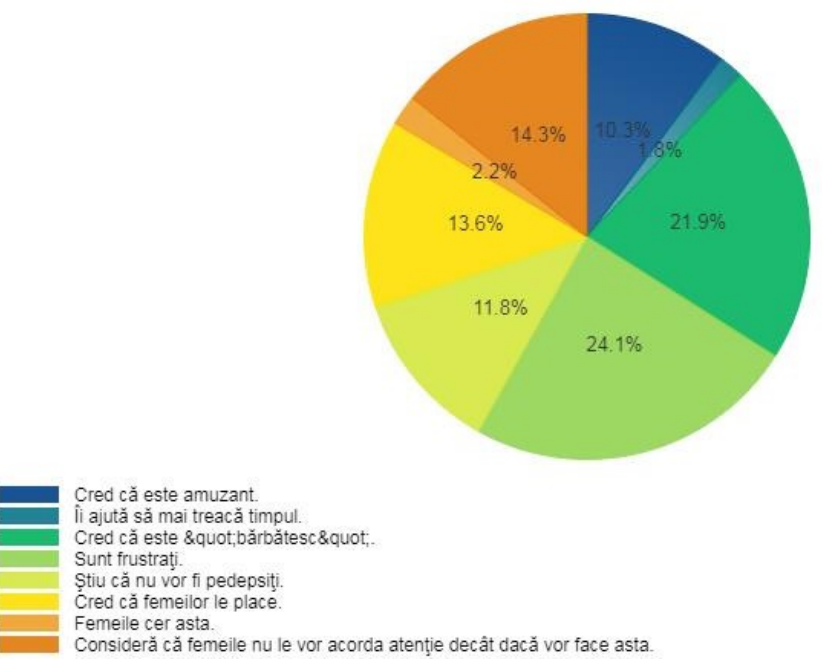

Fiind întrebați dacă au fost martori ai unor astfel de evenimente respondenții au spus: 32.5\% (65 de persoane) da, iar 67.5\% (135 de persoane) nu. R.S 


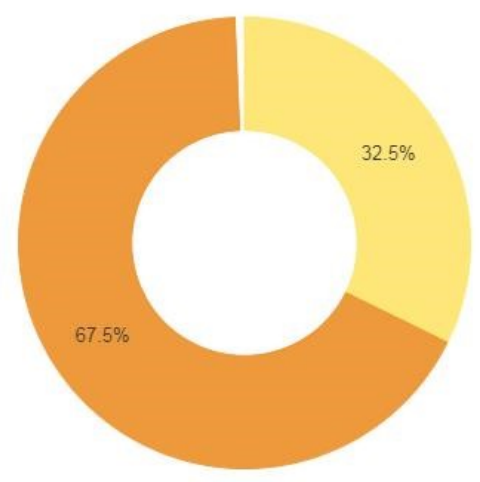

Da.

Persoanele care au răspuns afirmativ, au fost întrebate cum au reacționat la vederea unui astfel de incident. $11.5 \%$ (23 de persoane) au ajutat persoana aflată în cauză, 1.5\% (3 persoane) au trecut indiferente pe lângă, 58\% (116 persoane) au susţinut că nu au fost martore, iar 29\% (58 de persoane) susțin că nu a fost nevoie să intervină. R.S

Dacă da, cum ați reacționat?

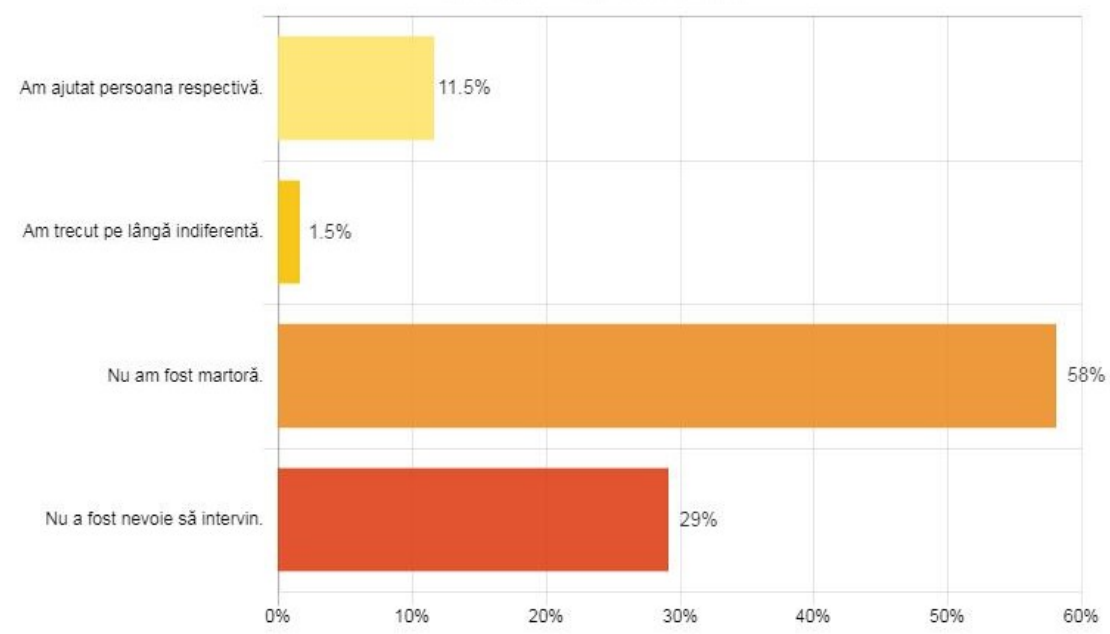

La întrebarea „Care credeți că este răspunsul societății cu referire la acest fenomen?", 33.9\% (75 de persoane) au spus că societatea este indiferentă, 9.5\% (21 de persoane) au susținut că aceasta este implicată, iar 56.6\% (125 de persoane) au susținut că majoritatea societății nu este interesată. R.M

\section{1}

How to cite: Spoiala, L.-C., Zaharie, R.-G., Petrea, M.-C., Smochina, S.-M., Clipa, M. (2017). Sexual Harassment. Micro-research. Logos Universality Mentality Education Novelty, Section: Law, V(2), 93-116. https://doi.org/10.18662/lumenlaw.6 


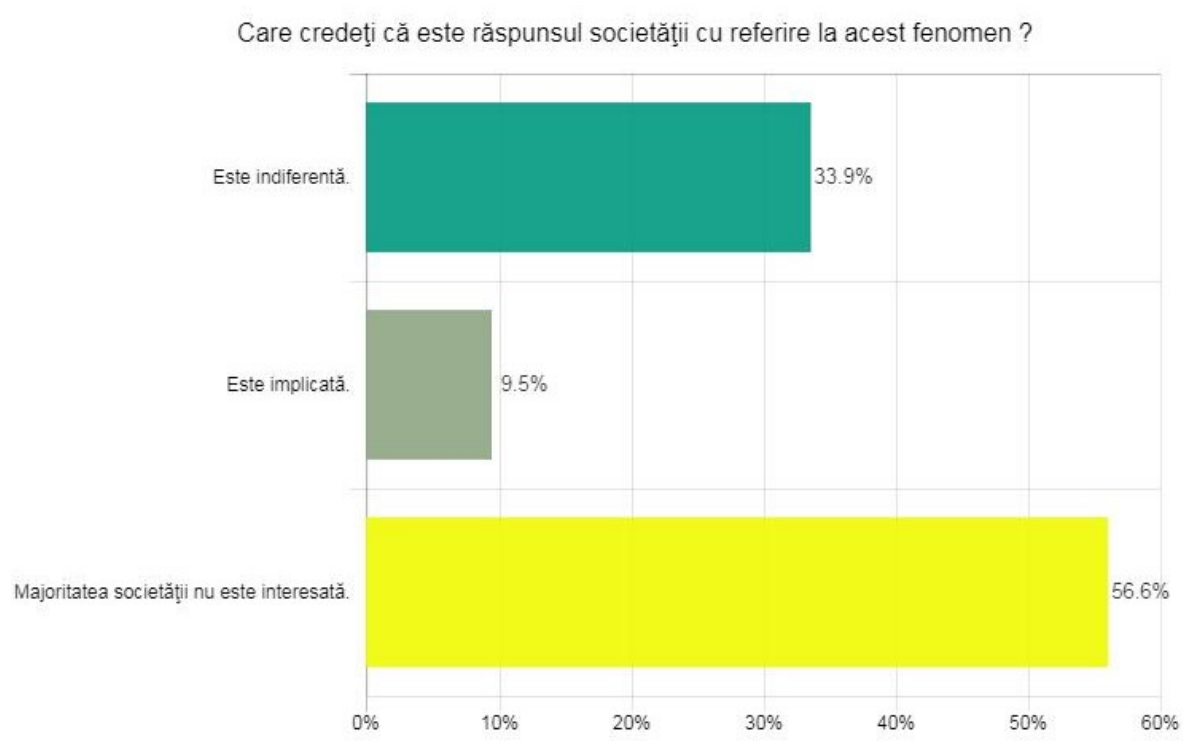

Toate persoanele chestionate în proporție de 100\% (200 de persoane) consideră că această problemă ar trebui să fie tratată cu mai mult interes de către autorități. R.S

Considerați că această problemă ar trebui să fie tratată cu mai mult interes de către autorități?

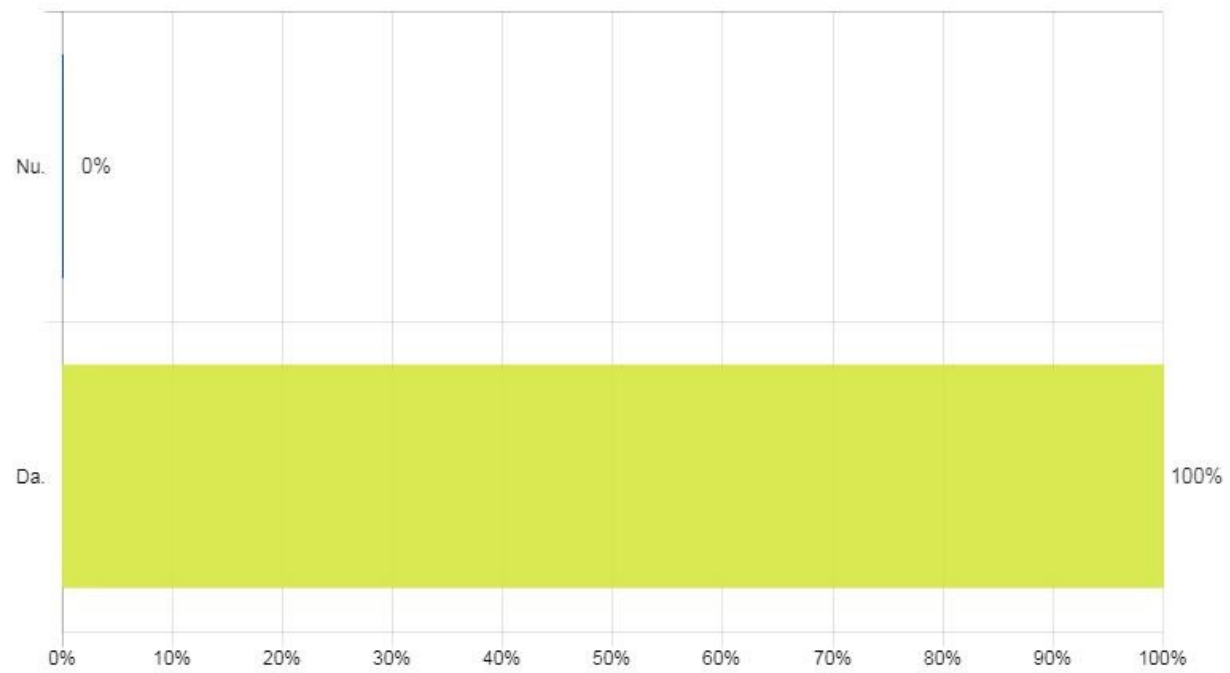

$\mathrm{Cu}$ privire la obstacolele diminuării acestui fenomen al hărțuirii sexuale, respondenții au spus: 15\% (30 de persoane) consideră că este vorba despre dezinteresul societății, 11\% (22 de persoane) consideră că este vorba despre dezinteresul autorităților, 48.5\% (97 de persoane) cred că este vorba

How to cite: Spoiala, L.-C., Zaharie, R.-G., Petrea, M.-C., Smochina, S.-M., Clipa, M. (2017). Sexual Harassment. Micro-research. Logos Universality Mentality Education Novelty, Section: Law, V(2), 93-116. https://doi.org/10.18662/lumenlaw.6 
de lipsa unor legi mai aspre, 25.5\% (51 de persoane) consideră că obstacolul este reprezentat de atitudinea delăsătoare a femeilor care sunt hărțuite. R.S

Care credeți că sunt obstacolele diminuării acestui fenomen al hărţuirii sexuale?

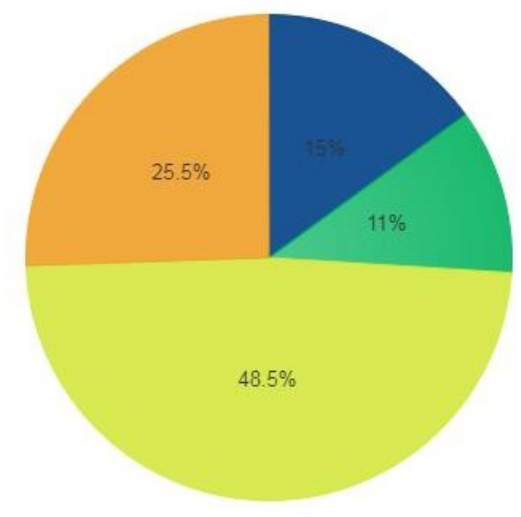

Fiind întrebate dacă ar raporta un astfel de incident, acestea au spus în proporție de 57.5\% (115 persoane) că da, ar face aşa întotdeauna; 30.5\% (61 de persoane) au spus că da, ar face asta dar sub anonimat; 7\% (14 persoane) au considerat că nu, nu este necesar, iar 5\% (10 persoane) au spus că niciodată, fiindcă nu văd niciun avantaj în acest lucru. R.S

Ați raporta un astfel de incident autorităților?

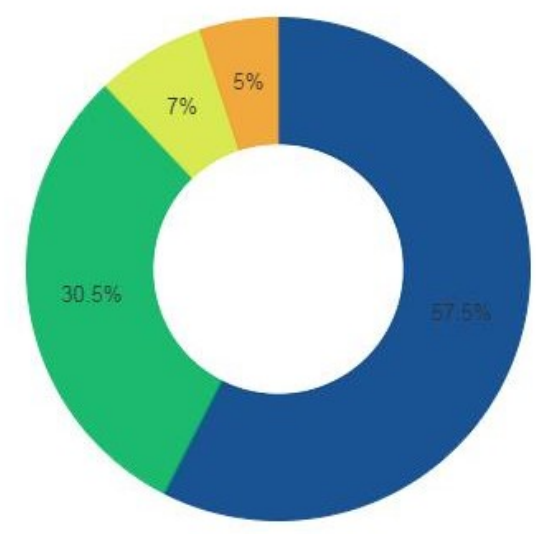

$\mathrm{Da}$, întotdeauna

$\mathrm{Da}$, dar sub anonimat.

Nu, nu cred că este necesar

Niciodată, nu văd nici un avantaj în acest lucru. 
Fiind întrebate care sunt motivele pentru care aceste incidente nu sunt raportate autorităților, respondentele au dat următoarele răspunsuri: $12 \%$ (50 de persoane) consideră că nu este un proces uşor de realizat; $23.1 \%$ (96 de persoane) consideră că motivul este lipsa cunoştințelor în legătură cu legile existente; $7.5 \%$ (31 de persoane) au dat drept motiv frica de autorități; 21.9\% (91 de persoane) au considerat că motivul este indiferența din partea autorităților; 5.8\% (24 de persoane) au spus că nu există nici un motiv şi că aceste incidente ar trebui raportate, iar cei mai mulți, respectiv 29.6\% (123 de persoane) au dat drept motiv frica de a nu fi agresate din nou.

În opinia dumneavoastă, care sunt motivele pentru care aceste incidente nu sunt raportate autorităţilor?

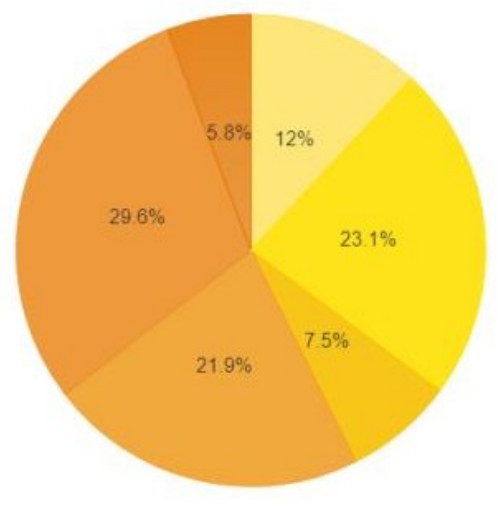

Nu este un proces ușor de realizat.

Lipsa cunoștințelor în legătură cu legile existente.

Frica de autoritătî.

Indiferenta din partea autoritătilor

Frica de a nu fi agresat din nou

Nu existä nici un motiv, aceste incidente ar trebui raportate.

Intrebarea inițială “Ați fost vreodată victima unei hărțuiri sexuale?” a fost reluată şi în finalul chestionarului pentru a vedea dacă răspunsurile inițiale coincid cu cele finale.

Dacă ințial 140 de persoane susțineau că nu au fost hărțuite, la această ultimă întrebare doar 123 de persoane au susținut acest lucru. R.M 


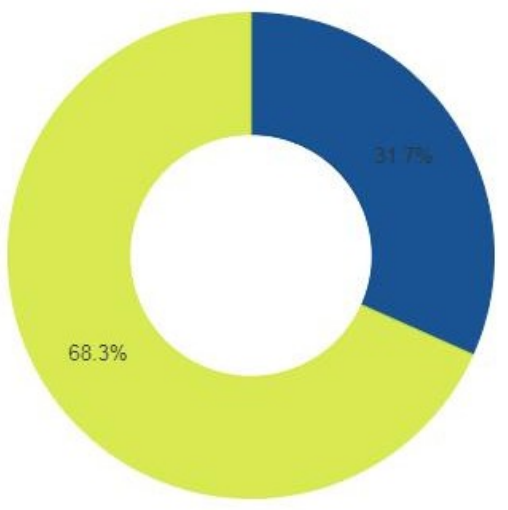

\section{Concluzii}

Cercetarea efectuată şi-a propus să evidențieze nivelul de informare al persoanelor de gen feminin cu privire la problema hărțuirii sexuale, modul de abordare al acestui subiect considerat de multe ori tabu, situațiile cu care se confruntă numeroase femei dar nu recunosc acest lucru, dar de asemenea şi modul de abordare al acestora atunci când vine vorba de rezolvarea acestor probleme.

Rezultatele arată în primul rând numărul persoanelor agresate sexual. Din cele 200 de persoane chestionate, doar 60 la sută au recunoscut că au fost hărțuite. Restul de 140 susțin că nu au fost, deşi, de-a lungul cercetării anumite răspunsuri eronate ne fac să credem că totuşi mai există un număr de persoane, care deşi au fost hărțuite, au preferat să suțină că nu au fost, acest lucru fiind de asemenea unul pe care am dorit să îl demonstrăm, femeile ascunzându-se de afişarea acestor experiențe, cu toate că ele erau sub anonimat.

O mare parte din persoanele chestionate, respectiv 39.5\% (79 de persoane) au recunoscut că nu cunosc decât o mică parte din legislația în vigoare la acest moment, legislație care apără persoanele aflate în aceste situații. Aproape acelaşi procentaj, respectiv 39\% (78 de persoane) au recunoscut că nu sunt informate şi nu cunosc legislația în vigoare. Răspunsul afirmativ a fost dat de doar 14.5\% (29 de persoane). 
Se poate remarca, de asemenea, realismul cu care s-a răspuns la intrebările privind importanța acestei probleme a hărțuirii sexuale, 57.5\% (115 persoane) spunând că sunt îngrijorate, iar 39\% (78 de persoane) susţinând că sunt total îngrijorate.

Prin intermediul cercetării efectuate am evidenţiat faptul că femeile aflate în astfel de situații nu cunosc legislația care le apără, nu cunosc informaţii precise referitoare la lucrurile cu care se confruntă, nu reuşesc să mărturisească ceea ce li s-a întâmplat şi consideră totuşi că acest subiect ar trebui mai mult să nu fie atins, chiar dacă, aproape toate persoanele chestionate au răspuns că sunt foarte îngrijorate în legătură cu acest subiect.

\section{References}

Agrosoaie, I., Gramada, S., Lupascu, C., Chirila, B., \& Scripcaru, G. (2003). Forensic and victimologic considerations about sexual abuse against persons of polar ages. Forensic Science International, 136 (Suppl 1): 275.

Miftode, V. (2011). Tratat de metodologie sociologică. Iaşi, România: Editura Lumen.

Sandu, A. (2016). Elemente de sociologie pentru administrația publică. Iaşi, România: Editura Lumen. 